




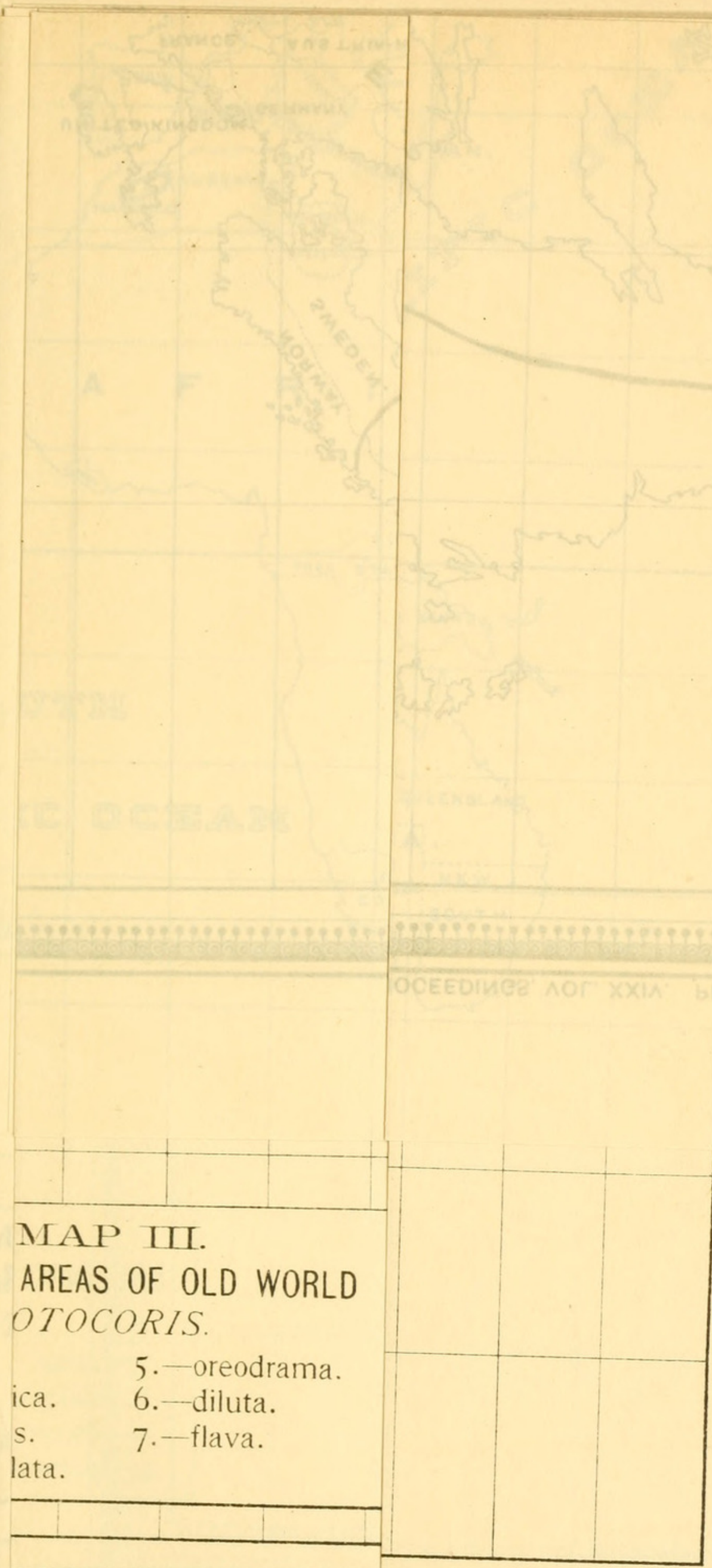





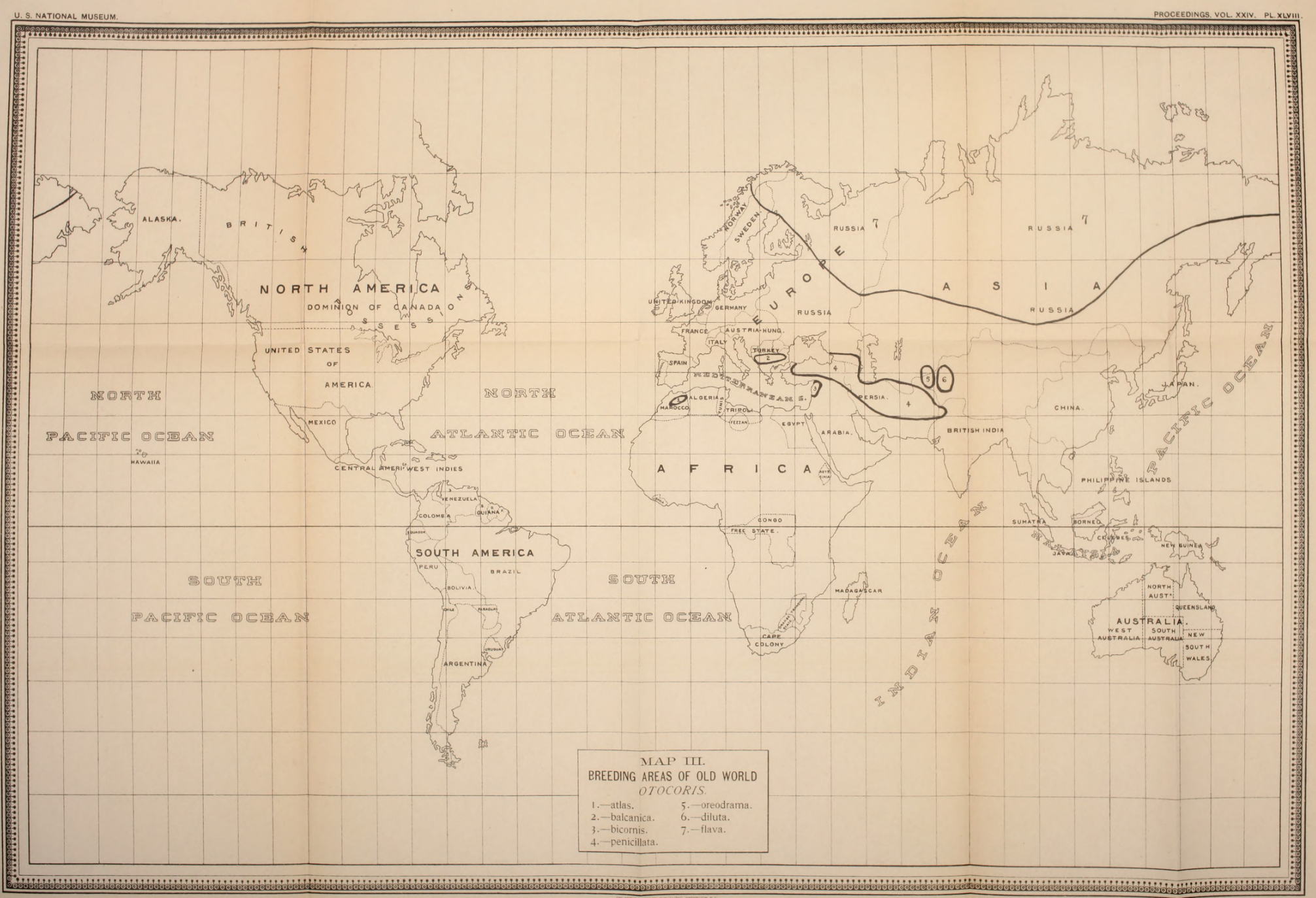





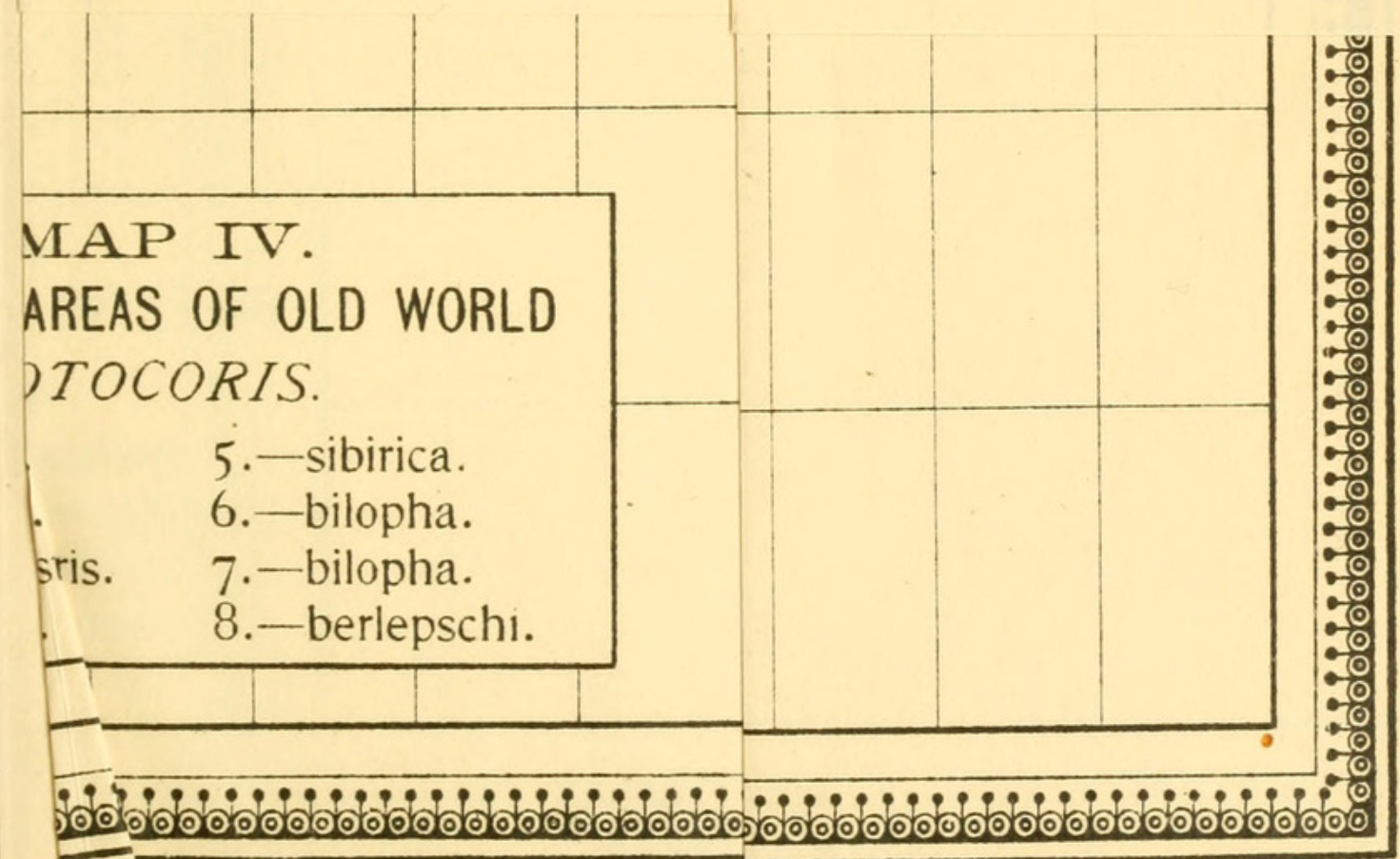





\title{
DESCRIPTIONS OF NEW DECAPOD CRUSTACEANS FROM THE WEST COAST OF NORTH AMERICA.
}

\author{
By Mary J. Rathbun, \\ Second Assistant Curator, Division of Marine Invertebrates.
}

The species and subspecies here described are the result chiefly of a study of the vast collection of shrimps from the coast of Alaska southward to San Diego, California, which have been accumulating for many years in the United States National Museum, and have been oktained largely by the United States Fish Commission steamer Albatross. Besides the shrimps, one new crab, an Oregonia, was dredged by the Albatross during her cruise in Bering Sea in 1900.

In connection with the publication of the Decapod Crustacea of the Harriman Expedition, it is proposed to give a list of the forms known to inhabit the coast of western America (north of Mexico) and to more fully describe and figure the new and little-known species.

\section{Family MAIID E.}

\section{OREGONIA BIFURCA.}

Surface tuberculate and hairy. Postorbital width two-thirds of branchial width. Rostral horns divergent from their base. Basal joint of antenna armed on its outer edge with a stout blunt subterminal spine and three small spines, one of which is at the anterior angle. Inner surface of merus of chelipeds bordered by short blunt spines; propodus slightly longer than merus, fingers and palm subequal, margins of palm subparallel. Dactyli of ambulatory legs contained about one and a third times in their propodi.

Dimensions. - Length of carapace and rostrum $26.5 \mathrm{~mm}$., width of carapace $19.6 \mathrm{~mm}$., width between tips of postorbital spines $13 \mathrm{~mm}$., length of horn measured along the inner edge $3.4 \mathrm{~mm}$., distance between tips of horns $3.5 \mathrm{~mm}$.

Type locality.-One specimen only, a female, was taken by the U.S. Fish Commission steamer Albatross at station 3785, north of Rat Islands, Aleutians, 270 fathoms (Cat. No. 25287). 
Family CALLIANASSID E.

\section{CALLIANASSA GONIOPHTHALMA.}

Closely allied to $C$. cxcigena Alcock and Anderson. Rostrum reaching barely one-third the length of the eyes. No median carina, but a slight blunt elevation near the posterior margin corresponding to the strong tooth in $C$. cxcigena. Eyes oblong, sides subparallel, reaching nearly to end of first antennular segment. Chelipeds of the first pair shaped as in $C$. cæcigena, but the carpus of the larger one is devoid of a spine, the palm is not serrated on its lower margin, its outer surface has a few tubercles irregularly disposed on the distal lower quarter; the pollex has on the cutting edge a stout tooth which is nearer the middle than in $C$. cxecigena. The second to fifth segments, inclusive, of the abdomen are without spines, the telson has subparallel side margins.

Dimensions.-Length of carapace of male $30.5 \mathrm{~mm}$., of abdomen $67.5 \mathrm{~mm}$.

Type locality. - Off Point Conception, California, 278 fathoms, station 3198, U. S. Fish Commission steamer Albatross, one male (Cat. No. 25238).

Distribution.-Also dredged in 322 fathoms in Clarence Strait, Alaska, station 3077.

\section{Family AXIID正.}

\section{AXIUS SPINULICAUDA.}

Gastric region traversed by five carinæ, all of which fade out before reaching the cervical groove; the median extends along basal third of rostrum and is armed with four spines; the outer carinæ are a continuation of the side margins of the rostrum, and are unarmed, as are also the shorter intermediate carinæ. Surface covered with rather distant scabrous granules. Rostrum reaches middle of second joint of antennular peduncle, is sharp-pointed, and has five spines on one side and six on the other. Second segment of antennular peduncle a little longer than the third, both together shorter than the first. The scaphocerite projects as far as the middle of the second segment of the antennula, the stylocerite to end of penult joint of antennal peduncle. First pair of chelipeds missing. Abdomen smooth above; pleura sculptured and pubescent; telson elongate, subquadrilateral, lateral margins spinulous, dorsal surface with a few spines; swimmerets spinulous.

Dimensions.-Female, length of carapace and rostrum $19.6 \mathrm{~mm}$, rostrum $3.5 \mathrm{~mm}$., abdomen $31.5 \mathrm{~mm}$.

Type locality.-One specimen only, from off Bodega Head, California, 62 fathoms, station 3172, U.S. Fish Commission steamer Albatross (Cat. No. 25239). 


\section{CALASTACUS QUINQUESERIATUS.}

Allied to $C$. felix Aleock and Anderson.

Carapace and rostrum as long as first five abdominal somites; surface pitted and setose. Rostrum reaches end of second antennular segment, is tipped with a spine, side margins armed with three to seven spines, and prolonged two-thirds the length of gastric region, where they bear five or six spines; these prolongations form a horseshoe. Median carina with from two to six spines. Intermediate carina with from three to five spines. Eyes colorless, globular. Stylocerite reaching to distal third of penult joint of peduncle; scaphocerite not reaching middle of stylocerite. Chelipeds unequal, the longer one in the male nearly as long as the body. Outer surface of carpus and hand covered with sharp granules or short spines; upper margin spinous, also lower inner margin of merus; lower outer margin of merus spinous; lower margin of propodus granulous. Margins of propodus subparallel, fingers shorter than palm in adult males, usually slightly gaping at base.

Abdomen almost smooth, sides setose. Anterior margin of pleura of third, fourth, and fifth somites, and lower margin of sixth, armed with a small spine. Telson subquadrangular, broadly rounded behind, having a few lateral and one median marginal spine, and two larger dorsal spines.

Dimensions.-Male, length of carapace and rostrum $28 \mathrm{~mm}$., of abdomen $41 \mathrm{~mm}$.

Type locality.-San Luis Obispo Bay, California, 200 fathoms, station 3196, U.S. Fish Commission steamer Albatross (Cat. No. 25240).

Distribution.-Also taken at six other stations on the coast of southern California, in 160 to 388 fathoms.

\section{Family PENAIDA.}

\section{GENNADAS BOREALIS.}

Allied to G. parvus Bate. Rostrum longer, reaching at least half way along the eyestalk, sometimes to the cornea; armed with one tooth. Median carina very distinct nearly to posterior border of carapace. A sharp marginal spine at angle of antero-lateral sinus. The antennal scale projects beyond the antennular peduncle by about the length of the last segment of the peduncle. Chelæ of first pair of feet narrow and elongate as in the succeeding pairs. Sixth abdominal somite more than twice as long as fifth, carinate. A small lateral spine at the posterior fourth of the telson. The thelycum differs from that of $G$. parvus in having the transverse plate between the feet of the fourth pair subquadrilateral, narrow in front, and that between the fifth pair fan-shaped, narrow behind, anteriorly rounded, and with 
a blunt median point. The leaves of the andricum are small and not in contact.

Dimensions.-Male, length of carapace and rostrum, $13.6 \mathrm{~mm}$; of abdomen, $29 \mathrm{~mm}$.

Type locality.-Off Copper Island, Kamchatka, 1,567 fathoms, station 3783, U. S. Fish Commission steamer Albatross (Cat. No. 25241).

Distribution.-Also taken in Bering Sea, north of Rat Islands, Aleutians, 850 fathoms, station 3784 .

\section{Family CRANGONIDA.}

\section{Genus CRANGON.}

a. Group of C. nigricauda, in which the carapace has only one median spine. and the gastric region is not depressed below the general level.

\section{CRANGON ALASKENSIS ELONGATA.}

Dr. S. J. Holmes, in his very useful Synopsis of California StalkEyed Crustacea, ${ }^{1}$ has given the synonymy and diagnoses of seven species of Crangon known to occur on the west coast of the United States. I would exclude Crangon alaskensis Lockington from the synonymy of C. nigricauda Stimpson, and raise it to specific rank, as in a large series of specimens it differs from $C$. nigricauda in the antennal scale being a little longer and much narrower distally, the extremity of the blade not produced at the antero-internal angle, the spine longer; the first pair of trunk feet shorter; hands more slender, their distal margin more oblique. C. nigricauda ranges from British Columbia to Lower California, $C$. alaskensis from Bering Sea to Straits of Fuca.

Typical $C$. alaskensis passes by insensible gradations into a form occurring off the coast of California and Oregon in 9 to 53 fathoms, which differs in its longer and narrower rostrum, in the outer antennular flagellum falling considerably short of the antennal scale, in the much longer scale, equal to the length of the carapace exclusive of the rostrum, in the fourth segment of the abdomen showing signs of carination, in the telson flattened above, though scarcely grooved, while its tip is more acute than in typical $C$. alaskensis.

Dimensions.--Length of ovigerous female from tip of rostrum to tip of telson, $55.7 \mathrm{~mm}$.; length of carapace, $13.5 \mathrm{~mm}$; of antennal scale, $11.6 \mathrm{~mm}$.

Type locality.-Off Santa Barbara, California, 29 fathoms, U. S. Fish Commission steamer Albatross stations 2970 and 2971 (Cat. No. 25242).

\section{CRANGON HOLMESI.}

Allied to $C$. alba Holmes in not having a groove on the under side of the sixth abdominal somite. Carapace a third as long as abdomen; rostrum short, narrow, triangular, tip rounded. Antennal scale as 
long or nearly as long as the carapace, exclusive of rostrum. Maxillipeds exceeding scale, antepenult segment not dilated. Hand elongate, about three times as long as wide.

Dimensions.-Ovigerous female, length, $23 \mathrm{~mm}$; of carapace, 5.3 $\mathrm{mm}$; of antennal scale, $4.2 \mathrm{~mm}$.

Type locality.-Off Wilmington, California, 27 fathoms, U. S. Fish Commission steamer Albatross station 2939 (Cat. No. 25243).

\section{CRANGON DALLI.}

Rostrum long and narrow. Acicle about seven-tenths as long as carapace, obliquely subtruncate, inner angle of extremity rounded, receding, spine extending beyond the blade to no greater extent than anterior width of blade. Hands widening from proximal to distal end, distal margin transversely oblique, length of palm about two and two-thirds its width. Sixth abdominal somite with two blunt prominent carinæ, which are the most distinguishing feature of the species.

Dimensions.-Length of ovigerous female, $61.5 \mathrm{~mm}$; of carapace, $16.2 \mathrm{~mm}$; of scale, $11.5 \mathrm{~mm}$.

Type locality.-Bering Sea, off Cape Seniavin, Alaska, 30 fathoms, U. S. Fish Commission steamer Albatross station 3287 (Cat. No. 25244).

Distribution.-One of the most abundant of Alaskan shrimps. Ranges from Bering Sea to Washington and to Kurile Islands, in $4 \frac{1}{2}$ to 61 fathoms.

\section{CRANGON FRANCISCORUM ANGUSTIMANA.}

Differs from typical $C$. franciscorum chiefly in the shape of the hands, which are narrower, the difference being greater in the male than in the female (in the male the length is five and a half times the width), the dactylus is more longitudinally placed, the pollex is more transverse and nearer the proximal end of the hand.

Dimensions.-Length of female $70.6 \mathrm{~mm}$., of carapace $18.9 \mathrm{~mm}$., of scale $13 \mathrm{~mm}$.

Type locality.-Off Chuckanuts Island, Bellingham Bay, Washington, 11 fathoms, station 3612, U. S. Fish Commission steamer Albatross (Cat.No. 25245).

Distribution.--Ranges from British Columbia to Oregon, in 23 to 67 fathoms.

b. Group of C. communis, in which the carapace has two median spines and the gastric region is not depressed below the general lecel.

\section{CRANGON RESIMA.}

Anterior of median spines much the smaller. Rostrum advanced beyond eyes, ascending, and having, in full-grown individuals, an inferior plate, thin, compressed, spatulate. Second segment of antennular peduncle three times as long as third. Hands shorter than in 
C. communis, three times as long as broad; their anterior margin and also the dactylus, when flexed, are more longitudinal than in C. communis.

Dimensions.-Length of ovigerous female $48.3 \mathrm{~mm}$., length of carapace $12.2 \mathrm{~mm}$., of scale $8.2 \mathrm{~mm}$.

Type locality. - Off San Diego, California, 124 fathoms, U. S. Fish Commission steamer Albatross station 2935 (Cat. No. 25246).

Distribution.-Ranges from Monterey Bay, California, to San Domingo Point, Lower California, 44 to 266 fathoms.

\section{CRANGON ABYSSORUM.}

Integument very thin. Anterior of median spines minute. Rostrum linear, flattened above, acute, ascending at an angle of 30 degrees, below compressed. Eyes very large, hemispherical, inner faces flat and contiguous. Second segment of antennulæ about one and a half times as long as third. Maxillipeds exceeding scale by half length of terminal segment. Manus widening distally, length three times width, dactylus more longitudinal than transverse. Sixth abdominal somite having two prominent dorsal carinæ and a short, low, lateral carina.

Dimensions.-Length of female $61 \mathrm{~mm}$., of carapace and rostrum $17 \mathrm{~mm}$., of scale $10.3 \mathrm{~mm}$.

Type locality.-Bering Sea, southwest of Pribilof Islands, 1,771 fathoms, station 3603, U. S. Fish Commission steamer Albatross (Cat. No. 25247).

Distribution.-Extends from Bering Sea to southern end of California, in 685 to 1,771 fathoms.

c. Group of C. munita, in which the gastric region is depressed below the general level of the carapace.

\section{CRANGON ACCLIVIS.}

Compared to $C$. munita Dana, the lower lateral spine of carapace is further back, the anterior median spine is much larger and farther forward, projecting well in front of the posterior line of the orbits; the rostrum is narrower, ascending at an angle of about 45 degrees, and the anterior margin of the hand is more longitudinal.

Dimensions.-Length of male $24.8 \mathrm{~mm}$., length of carapace $7.4 \mathrm{~mm}$., of scale $3 \mathrm{~mm}$.

Type locality.-Off Santa Cruz Island, California, 266 fathoms, station 2948, U. S. Fish Commission steamer Albatross (Cat. No. 25248).

Distribution.-Dredged from off the Trinity Islands, Alaska, to southern California, 80 to 266 fathoms; scarce.

\section{CRANGON VARIABILIS.}

Like $C$. munita, but carapace nearly half as long as abdomen, rostrum convex from behind forward, tip rounded and thickened. Outer 
margin of antennal scale concave. Second to fifth, inclusive, and sometimes the first, somites of abdomen carinated, and except on the first and second the carina is usually high, laterally compressed, and blunt.

Dimensions.-Female, length of body $32.2 \mathrm{~mm}$, of carapace $9.2 \mathrm{~mm}$.

Type locality.-Off North Head, Akutan Islanci, Alaska, 72 fathoms, station 2842, U. S. Fish Commission steamer Albatross (Cat. No. 25249).

Distribution.-Ranges from Bering Sea to southern Ca'ifornia, 72 to 184 fathoms.

\section{CRANGON SPINOSISSIMA.}

Compared to $C$. variabilis, the lower lateral spine of the carapace is more nearly in line with the superior lateral spine; the anterior median spine is larger and farther forward, advancing to a ine in front of the posterior line of the orbits; rostrum narrower, longer, acute, and more ascending; hand longer and narrower. Differs from all allied species in having the somites of the abdomen armed laterally with spines.

Dimensions. - Female, length of body $36 \mathrm{~mm}$. of carapace $10.5 \mathrm{~mm}$.

Type locality.-Off Point Arena, California, 51 fathoms, station 3351, U. S. Fish Commission steamer Albatross (Cat. No. 25250).

Distribution.-Off Oregon and California, 51 to 96 fathoms.

\section{CRANGON SPINIROSTRIS.}

Differs from all others of the munita group in having a long suberect spiniform rostrum. Anterior median gastric spine similar to the rostrum. Orbital spine slender and ascending, antero-lateral spine directed upward and outward. Third, fourth, and fifth abdominal somites carinated.

Dimensions.-Female, length of body $35.4 \mathrm{~mm}$., of carapace 10.5 $\mathrm{mm}$.

Type locality.-North of Unalaska, 399 fathoms, station 3329, U. S. Fish Commission steamer Albatross (Cat. No. 25251).

\section{SCLEROCRANGON ALATA.}

A small species allied to $S$. boreas. Carapace only slightly broader than long, surface sculptured and pitted, two spines and a tubercle on median carina. Antero-lateral angles broadly alate. Spine of antennal scale advanced as far as or farther than the blade. Hand less than twice as long as broad. Abdominal pleura without spines.

Dimensions.-Male, length $38 \mathrm{~mm}$., length of carapace $11 \mathrm{~mm}$., width at branchial spine $10.7 \mathrm{~mm}$.

Type locality.-Admiralty Inlet, Puget Sound, 40 fathoms, station 2865, U. S. Fish Commission steamer Albatross (Cat. No. 25252).

Distribution.-From Bering Sea to Puget Sound, 6 to 91 fathoms. 


\section{NECTOCRANGON DENTATA.}

Differs from $N$. lar (Owen), with which it has been confused, in the carinæ of the sixth abdominal somite ending in a small sharp tooth or spine, and the more elongate hand, which is about five or more than five times as long as its width across the palm.

Dimensions. - Female, length of body $73 \mathrm{~mm}$, of carapace $19 \mathrm{~mm}$, of hand $10 \mathrm{~mm}$., width of palm $2.1 \mathrm{~mm}$.

Type locality.-Off Sitkalidak Island, Alaska, 69 fathoms, station 2855, U. S. Fish Commission steamer Albatross (Cat. No. 25253).

Distribution.-From Bering Sea eastward to Sitka and westward to Kamchatka, 6 to 96 fathoms.

\section{NECTOCRANGON OVIFER.}

A deep-water species, also closely related to $N$. lar. Median crest of carapace higher, spines more ascending, anterior marginal spines above the eyes longer and more deeply separated, eyes larger, abdomen shorter, median carina higher, carinæ of sixth somite terminating in a small spine or tooth. Eggs larger than in $N$. lar or $N$. dentata.

Dimensions.-Female with eggs, length $60 \mathrm{~mm}$., length of carapace $17.4 \mathrm{~mm}$.

Type locality.-Off the Trinity Islands, Alaska, 159 fathoms, station 2853, U. S. Fish Commission steamer Albatross (Cat. No. 25254).

Distribution.-Found in Bering Sea and along the Alaska Peninsula, 56 to 368 fathoms.

\section{NECTOCRANGON CALIFORNIENSIS.}

Allied to $N$. ovifer. Eyes smaller, spine of antennal scale projecting not so far beyond the blade, hands having the digital spine situated nearer the wrist, and the distal margin in consequence more longitudinal; above all, the first and second abdominal somites are noncarinate, and the carina of the third and fourth somites is rather feebly developed.

Dimensions.-Male, length of body $31 \mathrm{~mm}$, of carapace $8.6 \mathrm{~mm}$.

Type locality.-Off Santa Catalina Island, California, 80 fathoms, station 3664, U. S. Fish Commission steamer Albatross (Cat. No. 25255).

\section{NECTOCRANGON LEVIOR.}

Allied to $N$. crassa Rathbun, but has the first four abdominal somites noncarinate, except for a tubercle on the first, and the carinæ of the fifth and sixth somites less clearly marked than in that species. The pleura of all the somites have shallow depressions.

Dimensions. - Female, length $47.7 \mathrm{~mm}$, length of carapace $13.1 \mathrm{~mm}$. 
Type locality.-Admiralty Inlet, Puget Sound, 40 fathoms; station 2865, U. S. Fish Commission steamer Albatross (Cat. No. 25256).

Distribution. - Occurs sparingly from Aleutian Islands to Puget Sound, in 10 to 68 fathoms.

\section{Family HIPPOLYTIDA.}

Genus SPIRONTOCARIS.

a. Species having one or more supraorbital spines.

SPIRONTOCARIS ARCUATA.

Very closely allied to, and in part associated with, S. spina (Sowerby). In the adult female, the upper line of carapace and rostrum in profile forms a single curve, without the sinus shown in S. spina; posterior lobe of third abdominal somite shorter and broader than in that species, sixth segment considerably shorter, less than one and a half times as long as wide; dactyli of third to fifth pairs of feet shorter than in S. spina, that of last pair being contained at least three times in propodus.

Dimensions.-Female, length $53.8 \mathrm{~mm}$., length of carapace and rostrum $20 \mathrm{~mm}$., of rostrum $8 \mathrm{~mm}$.

Type locality.-Washington Sound, Straits of Fuca, 48 fathoms; station 2864, U. S. Fish Commission steamer Albatross (Cat. No. 25257).

Distribution.-From Bering Sea to Straits of Fuca, in 3 to 350 fathoms.

\section{SPIRONTOCARIS MURDOCHI.}

Hippolyte spinus Murdoch, Report Internat. Polar Exped. to Point Barrow, Alaska, 1885, p. 140 (not Cancer spinus Sowerby).

Allied to S. spina (Sowerby) and S. liljeborgii (Danielssen). Description of female: Rostrum three-fourths as long as remainder of carapace, not reaching tip of antennal scale; midrib nearly horizontal; upper limb convex, 20 to 22 small irregular teeth; lower limb deeper, convex, 1 to 4 small teeth near end. Eyes as wide as the antennular peduncle and half its scale. Spine of antennal scale advanced about as far as blade. Dactyli of last three pairs of feet long and slender, that of last pair half as long as propodus. Abdomen not carinate; sixth segment three-fourths as broad as long.

Dimensions.-Female, length $46.6 \mathrm{~mm}$., length of carapace and rostrum $17 \mathrm{~mm}$., of rostrum $7.5 \mathrm{~mm}$.

Type locality.-Off Robben Island, east coast of Saghalin, Okhotsk Sea, station 3650, U. S. Fish Commission steamer Albatross (Cat. No. 25258).

Distribution.-Also taken on the east coast of Kamchatka and Arctic coast of Alaska. 


\section{$2 \mathrm{BHL}$ Biodiversity Heritage Library}

Rathbun, Mary Jane. 1902. "Descriptions of new decapod crustaceans from the west coast of North America." Proceedings of the United States National Museum 24(1272), 885-905. https://doi.org/10.5479/si.00963801.1272.885.

View This Item Online: $\underline{\text { https://www.biodiversitylibrary.org/item/53718 }}$

DOI: https://doi.org/10.5479/si.00963801.1272.885

Permalink: https://www.biodiversitylibrary.org/partpdf/53115

\section{Holding Institution}

Smithsonian Libraries

\section{Sponsored by}

Smithsonian

\section{Copyright \& Reuse}

Copyright Status: Public domain. The BHL considers that this work is no longer under copyright protection.

This document was created from content at the Biodiversity Heritage Library, the world's largest open access digital library for biodiversity literature and archives. Visit BHL at https://www.biodiversitylibrary.org. 